\title{
Independent and competing agencies: An effective way to control government
}

\author{
Reiner Eichenberger · Mark Schelker
}

Received: 23 February 2005 / Accepted: 20 June 2006

(C) Springer Science + Business Media B.V. 2006

\begin{abstract}
Controlling government is a primary focus of the politico-economic literature. Recently, various political institutions have been analyzed from this perspective, most importantly balanced budget rules, fiscal federalism, and direct democracy. However, one type of institution has been neglected so far: elected competitors to the government. Such institutional competition between the government and an independent agency can be found at the Swiss local level, where finance commissions compete with the government. In some parts of Switzerland, local finance commissions can ex ante criticize government projects and bring alternative policy proposals onto the political agenda, which are then voted on by the citizens. Thus, they become strong competitors to the government. We econometrically investigate this institutional setting by comparing the 26 Swiss cantons. We find the power of the local finance commission to have an economically relevant, statistically significant and robust negative effect on the tax burden and on public expenditures.
\end{abstract}

Keywords Political economics · Political control institution - Institutional competition · Audit court

JEL classification: D70, H10

\section{Introduction}

High taxes are a heavy burden on citizens, but the resulting revenues make governing more comfortable. Thus, there is an inborn conflict between citizens and the government over taxes and the allocation of public funds. Political economists keep searching for more effective institutional designs that prevent politicians from overextending taxation and public expenditures. One strain of the literature has investigated how different decision making processes empower citizens. These analyses have focused on representative-democracy (e.g. Persson

R. Eichenberger · M. Schelker $(\square)$

Center for Public Finance, University of Fribourg, Blvd. de Perolles 90, CH-1700 Fribourg, Switzerland e-mail: Mark.Schelker@unifr.ch 
\& Tabellini, 2000; Mueller, 2003; Besley \& Case, 2003), direct democracy (e.g. Matsusaka, 1995; Feld \& Kirchgässner, 2001; Feld \& Matsusaka, 2003), as well as fiscal decentralization in the form of federalism (e.g. Oates, 1999; Feld, Kirchgässner \& Schaltegger, 2003). Another part of the literature has concentrated on constitutional rules to directly constrain public spending, most importantly on balanced budget rules and the position of the Minister of Finance in the budget process (e.g. von Hagen, 1991, 2002; Alesina \& Perotti, 1996; Bohn \& Inman, 1996; Poterba, 1996; Schaltegger, 2002).

In this paper, we analyze a so far neglected option: institutionalized competition among elected agencies, i.e. consciously designed, formalized, and permanent competition between government and an independently elected political unit. Both of these bodies can make policy proposals that are then evaluated by the citizens. This type of political competition is similar to market competition where the products of different companies are in permanent competition. We presume that such institutionalized competition generates more policy alternatives, reduces information asymmetries, induces politicians to cater to the preferences of the citizens, and fosters a more efficient allocation of resources.

Although such a model might look utopian at first sight, it has existed for a long time in Switzerland. There, at the local level, institutionalized competition between government and independent audit units is a matter of fact. Many of these audit units have encompassing ex ante control and amendment rights, which make them powerful competitors to the government. We econometrically investigate whether such institutional competition results in a lower tax burden and less government expenditures. Our dataset consists of the 26 Swiss cantons (a canton is similar to a state in the U.S.). We use OLS and 2SLS models and estimate the influence of different political institutions such as direct democracy, decentralization as well as independent and competing agencies on the cantonal tax burden and government spending. Based on these findings, we offer a brief outlook for future research and applications.

Section 2 discusses the theoretical foundations of institutionalized competition in a direct democratic environment. The following third section presents empirical evidence that supports our theoretical hypothesis. In the fourth section we note some future research questions and conclude.

\section{Institutional competition and the case of Switzerland}

To our knowledge, institutionalized competition between the government and an independent political agency has not yet been analyzed. Of course, various independent institutions have been discussed, most prominently independent central banks (e.g. Alesina \& Summers, 1993; Berger, de Haan \& Eijffinger, 2001) as well as supreme courts (e.g. La Porta, Lopez-de-Silanes, Pop-Eleches \& Shleifer, 2004; Feld \& Voigt, 2003). However, in these cases the focus has not been on competition between institutions, but on the separation of competences. Furthermore, different forms of competition in political markets have long been discussed. For instance, Breton and Wintrobe (1975) demonstrate in their response to Niskanen $(1967,1971)$ that even in a bureaucracy competition emerges when resources are scarce. In the "checks and balances" approach competition is a consequence of (often intentionally created) conflicts of interest between institutions (Persson, Roland \& Tabellini, 1997). The struggle between the conflicting interests, however, is resolved by consensus between the affected bodies themselves. Another example is committees with overlapping jurisdictions. As in the checks and balances approach, the committees mostly resolve their 空 Springer 
conflicting interests by cooperation (King, 1997). But obviously, resolution of conflict through cooperation contrasts with our model of competition in which citizens decide between the competing alternatives in a popular vote. Hence, we strictly follow the market analogy, where consumers decide between different consumption alternatives.

In the following analysis of institutional competition, we focus on the very simple setting of a direct democracy. In this simple setting the citizens elect the government as well as a competitor to the government. In a town meeting the government presents its policy proposals for the following period, while the competitor may analyze the government proposals and may be permitted to present its counterproposal. The citizens choose in a majority vote between the status quo and the two competing proposals and delegate the policy implementation to the government. The competitor has no direct influence on the political outcome, because he has neither voting rights nor the power to implement his own proposals. After the government has fulfilled its assignment, the competitor can evaluate whether the government executed the task according to the law. As the two bodies compete for the approval of their proposal, we anticipate the proposals to better reflect median voter preferences. Thus, fruitful competition can result in policy outcomes closer to the median preferences.

Such intense institutionalized competition can be observed at the Swiss local level in municipalities with town meetings. In Switzerland more than 50 percent of the total population lives in such municipalities. Citizens elect the government as well as an independent finance commission, which can take the role of the competing political agency. The cantonal legislation on municipalities defines the basic institutional design of these finance commissions, but still leaves the municipalities some autonomy in the de facto design. While the intra-cantonal differences are very small, the inter-cantonal variations are important. In some cantons the finance commission can only audit the accounts or, similar to an audit court, criticize the government at the end of a fiscal year, i.e. ex post to all important decisions. However, in other cantons finance commissions have encompassing ex ante audit competences as well as proposal and amendment rights. In addition to the standard ex post audit of the accounts, they can ex ante evaluate the budget proposal, individual investment projects, as well as the tax rate. Moreover, they are allowed to advance concrete proposals, which are then voted on by the citizens. Thus, they become strong competitors to the government. Depending on cantonal legislation, finance commissions act as basic auditors, audit courts, institutional opposition, or even as a type of 'parallel' government.

From a theoretical point of view, institutionalized competition has five main implications.

1. The competitor informs citizens of financial and fiscal policy issues. This decreases information asymmetries as well as principal-agent problems between citizens, government, and the administration, which makes political decisions to better match the preferences of the citizens (see Eichenberger \& Serna, 1996). The benefits are the greatest, when the additional information is provided ex ante to the decision process.

2. The competitor breaks the agenda setting monopoly of the government. Usually, the government or committees decide on the political agenda. Thus, they significantly affect the political results (see e.g. Weingast \& Marshall, 1988; Shepsle \& Weingast, 1994). As soon as the competitor has encompassing proposal and amendment rights, the agenda setting monopoly of the government is broken, which diminishes the asymmetric influence of the government. 
3. The proposals of the competitor and the government compete to win a majority of the votes. Citizens can express their preferences on the proposals of the government and the competitor directly via majority vote. Such direct competition is not only an effective incentive mechanism, but also a perfect feedback mechanism. It makes it easier for all market participants to evaluate success. Simultaneously, the visibility of the preferences of the general public to politicians improves. Both mechanisms tend to reinforce the intrinsic motivation of politicians to pursue the public interest (if there is such a motivation, see Frey, 1997).

4. The competitor has incentives to break up political cartels. The government and the opposition parties have the same incentives when it comes to political rents. A pertinent example is general tax cuts. Governments have no incentives to curb taxes; they would rather divert the revenues to their supporters. Unfortunately, political competition does not help, as the opposition parties cannot credibly commit to tax cuts, because cutting taxes will go against their interests, as soon as they are in power themselves. The competitor, however, is far more independent and does not have the same opportunity to extract rents from the political process. Firstly, the competitor has no direct influence on the political results as he has no executive powers. Therefore, he cannot directly benefit from political rents generated by, e.g., high taxes. Secondly, we observe in the Swiss case that on average the members of the competing institution emanate from another "selection" of politicians. Compared to a mandate in an executive position, the competitor mandate is less time consuming, and professional auditing know how can be transferred from the private sector to political office quite easily. Furthermore, members of the competing institution are less likely than government or parliament members to be career politicians and are far more often politicians only for a short period. Thus, they are less integrated within political networks and usually do not belong to the "classe politique".

5. Members of the competing agency have incentives to pursue constructive policies. At first glance, opposition parties may appear to play a role similar to the one of competing agency. However, they have strong incentives to pursue obstructive rather than constructive strategies for two reasons: First, political outcomes are attributed to the government rather than to the opposition parties. Second, opposition parties that choose constructive strategies run the risk that voters like their influence and thus do not elect them into government but rather want to keep them in this fruitful opposition role. Thus, taking a constructive position may worsen the electoral prospects of an opposition party. In contrast, members of the competing unit do not compete to be elected into government. They can only boost their chances to be reelected as competitors by pursuing constructive strategies and trying to improve political outcomes.

These five aspects induce the competitor to propose policy alternatives that are closer to median preferences. This, in turn, exerts competitive pressure on the government and thus, increases its incentives to cater to the citizens' demands. Of course, the beneficial effects are not dependent on auditors always becoming active to the full possible extent. As the contestable market hypothesis suggests, the incentives of the government are already affected by the potential activity of the auditors. As a consequence, the government is less willing to pursue policies that asymmetrically favor special interest groups. Therefore, we hypothesize that the allocation efficiency increases with the power of the competitor, i.e. when the competitor exhibits encompassing ex ante audit and proposal rights. We expect this 
to result in better fiscal performance as measured by lower government spending, deficits, public debt, tax levels etc.

\section{Empirical evidence at the Swiss local level}

Switzerland is a federal state and has - similar to the U.S. - a much decentralized political structure. The 26 cantons (similar to U.S. states) as well as most local municipalities enjoy a high degree of autonomy and make a wide range of political decisions independently. Therefore, the institutional design differs strongly across the 26 cantons. The cantons as well as the municipalities raise their own taxes to finance cantonal and local expenditures. These characteristics make the Swiss case particularly interesting for empirical research (for details see, e.g., Feld \& Matsusaka, 2003; Feld \& Kirchgässner, 2001).

\subsection{The data}

\subsubsection{The institutional competition variable}

At the local level, institutionalized competition between government and an elected competitor develops in communities with town meetings, because only in this institutional setting is the finance commission really independent. In parliamentary systems the finance commission is an ordinary committee (Weingast \& Marshall, 1988), with the exception of two larger Swiss cities, i.e. Olten as well as the financially most successful city of Switzerland, Zug. As this form of institutionalized competition has not yet been analyzed, no respective measure exists. To measure institutional competition we construct an index that captures the institutional design of the finance commissions in the 26 cantons. The intra-cantonal design is relatively homogenous, whereas the inter-cantonal variation is striking. In order to identify the de facto design, we first analyzed the (de jure) cantonal legislation on municipalities; then we investigated whether the communities made de facto use of the opportunities offered by cantonal law (see Schelker, 2002; Schelker \& Eichenberger, 2003). In line with ordinary supreme auditing institutions such as the US General Accounting Office, the European Court of Auditors, or the German "Rechnungshöfe", ${ }^{1}$ all local finance commissions carry out a standard audit of the accounts, may perform an ex post evaluation of economic efficiency, and submit an auditor's report. The finance commissions have no authority to enforce changes or to introduce sanctions. However, in contrast to ordinary audit courts, in many cantons the local finance commission has, in addition to the ex post auditing rights, encompassing ex ante control competences. They may audit and evaluate the proposed budget, individual investment projects as well as the tax rate ex ante. Furthermore, they may have extensive rights to propose amendments to government projects. To summarize, finance commissions may have one or more of the following competences:

\section{Audit competences}

- Ex post audit of the accounts

- Ex post audit of individual government projects

\footnotetext{
${ }^{1}$ For an economic analysis of supreme audit institutions, see e.g. Frey and Serna (1990), Frey (1994), Streim (1994), and Forte and Eusepi (1994).
} 
- Ex ante audit and evaluation of the government's budget proposal

- Ex ante audit and evaluation of individual government projects

\section{Amendment recommendations (to the citizens)}

- Right to issue opinions and recommendations on government propositions (acceptance/rejection)

- Right to advance alternative propositions

\section{Independence}

- Elected by the citizens (not appointed by government)

The audit competences define the item to be audited and at what moment the audit takes place (before or after execution). The "Ex post audit of the accounts" is the classical audit procedure, where the audit unit examines the reliability of the accounts and their compliance with general accounting standards. Under "Ex post audit of individual projects" the commission audits individual projects by evaluating the effectiveness of its implementation and identifying any misuse of public funds. Under "Ex ante audit and evaluation of budget proposal", the commission evaluates the budget proposal's compliance with accounting standards. Under "Ex ante audit and evaluation of individual projects", the commission evaluates the efficiency of individual investment projects before they are adopted and implemented. In order to effectively bring information into the political process, finance commissions need to have recommendation and amendment rights. We code each aspect with 1 (available) or 0 (not available) and aggregate them to form the finance commission index. We exclude "Ex post audit of the accounts" and "Recommendation with respect to the government proposition (acceptance/rejection)" from our index because the finance commissions of all communities exhibit these aspects (for details see Schelker \& Eichenberger 2003). Because only municipalities with town meeting feature such competing finance commissions, we multiply the finance commission index by the prevalence of town meetings in each canton. Thus, our measure of institutional competition is the product of the finance commission index and a variable measuring the fraction of people per canton living in a municipality with town meeting (for details see Appendix B).

Note that a lack of recommendation and amendment rights does not necessarily eliminate competition between the government and the finance commission. All cantons require an auditor's report from which interested citizens can obtain information about the finance commission's point of view. Therefore, relevant information may enter the political process even though recommendation and amendment rights are missing. But in this case the information and transaction costs must be borne by individual citizens. Thus, in a community where the finance commission has no recommendation and amendment rights, transaction costs are higher and information asymmetries more important than in communities where the finance commission enjoys encompassing recommendation and amendment rights. A related argument can be made with respect to audit competences. Even with limited audit rights, important information may be generated. But again, transaction costs for individual citizens are significantly higher. Hence, in communities with weak finance commissions, competition between government and the finance commission will be less intensive and the benefits to the citizens' inferior. Thus, the finance commission indicator is interpreted as a measure of intensity of competition. 


\subsubsection{The dependent variables}

As a consequence of the extensive decentralization of Switzerland, financial data at the municipal level is not easily available and often not comparable across cantons. The problem is even more serious for smaller communities, which are more likely to feature town meetings. There is, for instance, no standardized dataset on the fiscal performance of municipalities. Data on local public debt are only available for bigger cities whereas official data for the other municipalities are wild estimates. Data concerning local public spending are generally not comparable between the municipalities of different cantons. Moreover, the extent of decentralization varies across cantons. Thus, there is a substitution effect among municipal and cantonal spending (see Eichenberger, 1994; Schaltegger, 2001). For both reasons, we concentrate on the aggregate of local and cantonal data. Reliable data exists for the aggregate of the local and cantonal tax burden as well as public expenditures for each canton. The aggregated tax burden is an index constructed by the Swiss Federal Statistical Office and includes the taxes of the canton, the municipality, and the local official church communities (which have the power to tax) on a natural person's annual income. The data on aggregated local and cantonal public expenditures per capita include the cantonal government expenditures and the aggregated government expenditures from all municipalities in the same canton over a budget period divided by the cantonal population. Unfortunately, these data also include federal grants. Therefore, we have to eliminate the observations from the canton of Uri. A large share of the budget of this canton consists of huge federal infrastructure projects, which are fully funded by the federal government.

As we do not observe any significant variation in the institutional design in this period, we focus on cross-section evidence. Consequently, our empirical analysis is limited to 26 observations. Although this is in line with many cross-country analyses, we need to be cautious when interpreting the results. Nevertheless, the estimates look promising as we obtain statistically significant and robust results despite the limited sample-size.

\subsubsection{Control variables}

Tax rates and government expenditures are driven by a broad set of variables. From a politicoeconomic perspective, institutional features such as the effectiveness of direct democratic instruments at the local and cantonal levels as well as federalism in the form of fiscal decentralization must be considered. Therefore, we include various indicators for direct democracy and federalism in our model. Direct democracy at the local level is captured by the fraction of the population that lives in a community with town meetings. To specify the magnitude of direct democracy at the cantonal level we use the standard index proposed by Stutzer (1999) (see also Frey \& Stutzer, 2000, 2001), which aggregates all relevant aspects of the extent of direct democratic instruments available to citizens into a single indicator. To describe the degree of federalism in the form of fiscal decentralization in a specific canton we use an index proposed by Ladner (1994), which captures local autonomy as described by the local chief administrators in a systematic survey.

Of course, it would also be interesting to control for other political variables, such as the composition of the government and government fractionalization, which have been found to be relevant in explaining fiscal policy in cross-country as well as in US crossstate regressions. However, for the Swiss local level, data on the composition of the governments is neither available nor would it be very informative. As most members of Swiss local governments are elected on a personal basis in majority votes, all governments are fractionalized to a large extent. Moreover, many members of local governments 
are not members of a political party. Furthermore, it is difficult to compare political parties across cantons as even the cantonal sections of parties with nationwide activities largely differ between cantons, as is, e.g., evidenced in the fact that they often advance opposing recommendations for nationwide referenda. Therefore, we did not include measures for the political position as well as the composition of the government into our estimates.

To control for economic, topographic, demographic etc. aspects, which impact on public spending as well as on the tax burden, we include the cantonal per capita income, the average population size, the cantonal unemployment rate, an index measuring urbanity, an index measuring topography, the demographic structure, and a dummy for language affiliation (German 1, French and Italian 0).

According to the recent literature, we expect direct democratic instruments and federalism to have a negative influence on the tax burden and public expenditures. For the cantonal per capita income we anticipate a negative (positive) impact on the tax burden (spending). For population size we have no clear-cut expectations, as there are arguments in favor of both economies as well as diseconomies of scale. The unemployment rate can be expected to exhibit a positive impact on the tax rate as well as public expenditures since unemployment leads to higher welfare costs. Increasing values in the topography index imply higher topographic burdens and result in higher infrastructural costs and thus, in an increasing tax burden and public expenditures. Furthermore, we expect the share of the population living in urban areas to have a positive influence on our dependent variables. With respect to the demographic structure, we anticipate the working population to have a negative, and the non-working population to have a positive, impact on tax rates. We have no specific expectations for the language variable reflecting cultural background, however, as it is common for non-economists to argue that cultural background drives politics we control for this influence.

Table 1 presents the data used in our empirical investigation.

\subsection{Empirical results}

Our theory assumes that stronger institutional competition will lead (ceteris paribus) to a reduction of the aggregated communal and cantonal tax burden as well as public expenditures. Testing these hypotheses we focus on OLS estimates. However, such estimates could suffer from simultaneity and omitted variables. Effective institutions are not necessarily exogenously given, but can be the result of the specific fiscal preferences of the citizens. Thus, it could be argued that institutions such as powerful independent political units (finance commissions), direct democratic instruments, and federalism emerge endogenously and have no direct influence on taxes or expenditures. To address these factors, we also estimate 2SLS regressions (see Angrist \& Krueger, 2001). As instruments we use culture (language), topography, and urbanity. While Pujol and Weber (2001) show that in Switzerland fiscal preferences are correlated with linguistic provenance, it is common for studies dealing with Swiss datasets to include a language dummy to control for cultural background (e.g. Feld \& Matsusaka, 2003; Feld \& Kirchgässner, 2001; Frey \& Stutzer, 2000, 2001; Schaltegger \& Feld, 2001). Furthermore, cultural background (language or colonial origin) is often used in cross-country analysis to instrument institutional features (e.g. Persson \& Tabelini, 2004). We also assume that urbanity and topography could influence fiscal preferences and therefore, we use them as instruments when statistical requirements are met.

Springer 


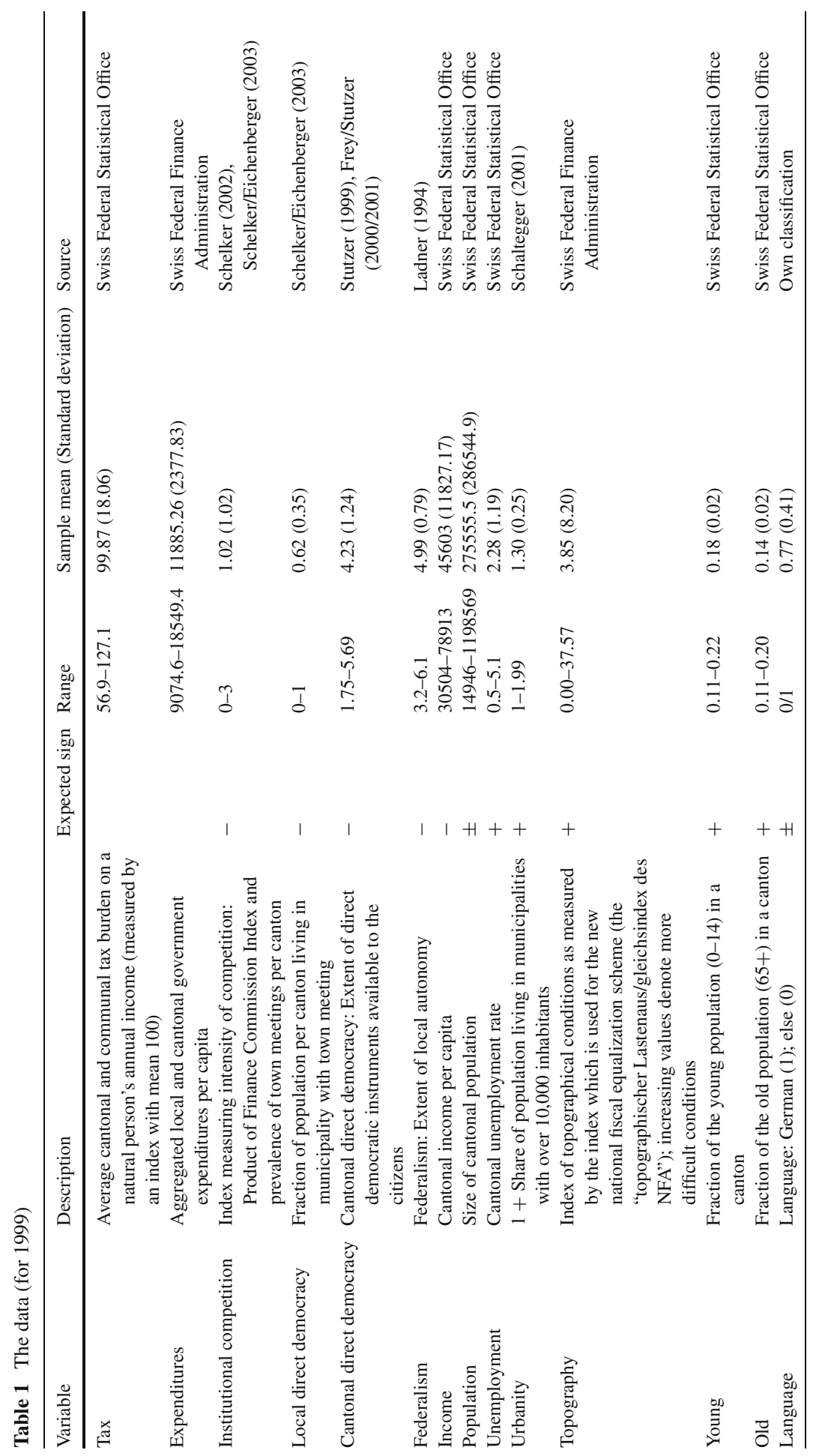




\subsubsection{Empirical analysis: Tax burden}

Table 2 presents the empirical results for the impact of institutional competition on the aggregate cantonal and local tax burden. Regression 1 is our base regression. Regressions 2 to 6 include additional explanatory variables that may influence our dependent variable. As we have limited degrees of freedom, we only introduce one additional variable at a time. All regressions include a dummy variable for the canton of Basle-Town. This canton is an outlier with respect to its average income, which impacts on our results. When excluding these observations from our sample the size of the estimated effect of our institutional competition variable decreases from -9.65 to -7.10 . We also estimated each model specification by deleting one canton after another from the sample. All effects remain statistically significant with coefficients clustering around $-7.1 .^{2}$

Column 7 provides the results of our 2SLS estimation. Due to omitted variable and simultaneity concerns we instrumented our institutional competition variable with three unarguably exogenous variables: language, urbanity, and topography. While, individually, they are not all statistically significant in the first stage regression on our institutional competition variable, they are jointly significant. We observe an increase in our main explanatory variable, but the tax decreasing effect is confirmed. As the results do not differ much and the institutions have been in place for quite a long time, endogeneity should not be a big concern. Furthermore, a Durbin-Wu-Hausman test confirms exogeneity of the institutional competition variable. Thus, OLS should yield consistent estimates. Therefore, we will mainly focus on the efficient and more conservative OLS estimates.

The results from Table 2 confirm the expected theoretical effects of institutional competition between the government and an independent political agency. As the dataset relies on a limited number of observations, it is more difficult to obtain statistically significant results. In regression 1, the influence of the institutional competition variable on the aggregated cantonal and local tax burden is not only statistically significant, but also economically relevant. A one point increase of the institutional competition variable implies an average reduction of the tax burden of 7.10 percentage points. Since the institutional competition variable ranges from 0 to 3 a potential difference of roughly 21 percentage points results. Taking into account that the average tax burden is standardized to 100 percent, the potential effect is very large. In regressions 2 to 6 the results seem to be robust to the inclusion of additional explanatory variables and remain statistically significant. ${ }^{3}$

In contrast to institutional competition, cantonal direct democracy does not exhibit a statistically significant influence on the aggregated cantonal and local tax burden. At first sight, this result is not fully in line with the emerging literature on direct democracy which tends to find beneficial impacts of direct democracy on public finance variables. However, it can

\footnotetext{
2 The most extreme values result when dropping the observations for the cantons Fribourg and Graubünden. In the case of Fribourg the size of the coefficient increases to -11.2, in the case of the canton of Graubünden, it decreases to -5.9. The canton of Fribourg is also interesting for another reason. Its finance commissions were most difficult to classify. They have no formal right to advance alternative proposals but are allowed to ponder alternatives. Thus, they regularly develop alternative ideas which then are taken up by a citizen who formulates them as a formal proposal which has to be voted on. Therefore, we classified the finance commission index value of Fribourg to be 4. But from a more restrictive perspective one could also argue that a value of 3 is appropriate. When reclassifying Fribourg accordingly, the coefficient for institutional competition is (absolutely) increasing to -8.50 with increasing statistical significance.

3 The results including the canton of Basle-town are even stronger. The coefficient is with -9.65 higher and the standard errors are smaller. Apart from the income variable, no other variable is significantly affected by the inclusion of the canton of Basle.
} 


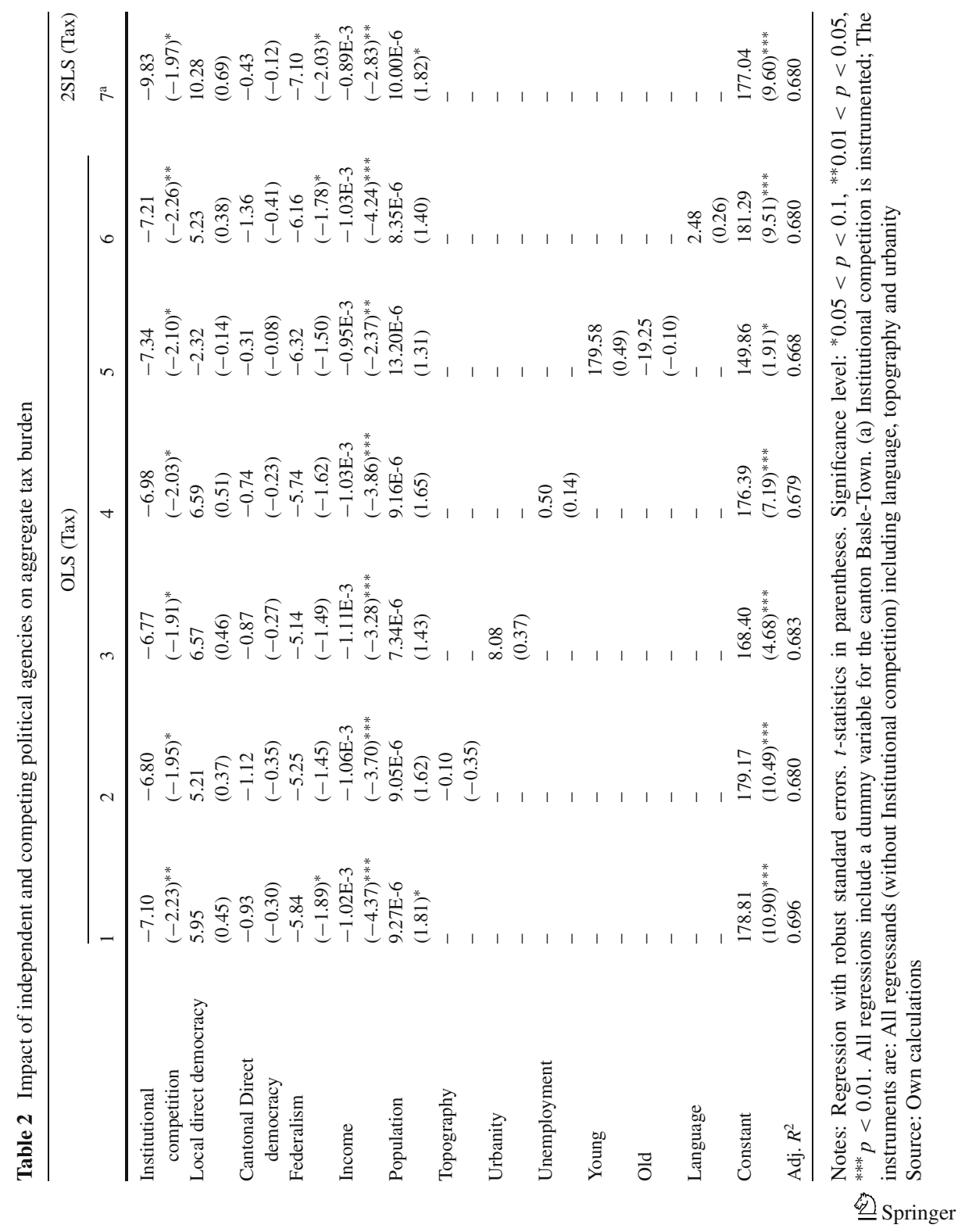


be easily reconciled with that literature for several reasons: First, most earlier studies did not focus on the influence of direct democracy on the tax burden but rather on expenditures, deficits, and debts. Second, earlier studies often focus on cantonal level data only, but not on the aggregate of local and cantonal data. As we have already argued, studies analyzing Swiss fiscal institutions should take both levels into account simultaneously because there is systematic substitution between cantonal and local government activity (Eichenberger, 1994; Schaltegger, 2001). Third, the influence of the cantonal direct democracy variable is sensitive to the inclusion of other explanatory variables such as urbanity, demography, share of foreigners or unemployment. ${ }^{4}$ Solely if we exclude all other institutional variables and estimate cantonal direct democracy together with population and income only, we find statistically significant negative effects. Forth, earlier studies did not include local direct democracy measures in their estimates, even though a large portion of fiscal decisions are made at the local level. As with most other variables, the inclusion of the local direct democracy variable renders cantonal direct democracy insignificant. However, these two variables are correlated with 0.63 , what might boost the standard errors. ${ }^{5}$ The correlation between the institutional competition variable and local as well as cantonal direct democracy is with a 0.48 and 0.39 , respectively, lower and should not cause too many problems. The institutional competition variable on the other hand is not sensitive to the inclusion of the cantonal direct democracy variable or any other institutional variable.

Local direct democracy in the form of town meetings does not exhibit significant effects on the aggregated local and cantonal tax burden. However, this variable is, similar to the measure of direct democracy at the cantonal level, also sensitive to the inclusion of other variables.

Federalism exhibits a strong negative and sometimes statistically significant impact on taxes. For every unit of increasing local autonomy, we estimate an average influence of -5.84 percentage points. Considering a range from 3.2 to 6.1 we observe a potential effect of up to 16.8 percentage points lower tax burden. Thus, local autonomy also seems to be an important ingredient in lowering taxes. While the size of the coefficient is not much affected by the inclusion of additional control variables, statistical significance falls below conventional levels.

Consistent with our expectations, the cantonal income variable exhibits a negative impact on taxes. The coefficient remains quite stable to changes in the setting and is regularly statistically significant at least at the 5 percent level. An increase of cantonal income by CHF 1000 implies an average tax reduction of around 1 percentage point. Population size exhibits only at the margin a statistically significant influence on our dependent variable. Sometimes it is assumed that population size affects public finance non-linearly. Thus, we also included the quadratic term of population size into the equation (not reported in Table 2), but the results remain unchanged. All other variables from regressions 2 to 6 are statistically not significantly different from zero. The variable for topography has no statistically significant explanatory power. This is not surprising, because a great part of extra infrastructural costs due to topographical conditions are born by the central government and therefore, do not affect taxes in these regions. Urbanity, the unemployment rate, and demographic

\footnotetext{
${ }^{4}$ See also the dispute between Bodmer (2004) and Kirchgässner (2005).

${ }^{5}$ However, when we only include either cantonal or local direct democracy together with the other control variables in our regression the results for direct democracy do not change much. For instance, when we drop local direct democracy from our base equation, the coefficient for cantonal direct democracy shifts from -0.93 $(t$-value -0.30$)$ to $-0.17(-0.05)$.
} 
factors exercise no statistically significant influence on the aggregated local and cantonal tax burden.

\subsubsection{Empirical analysis: Public expenditures}

Following the same empirical strategy as before, we detect very similar patterns and largely the same results with respect to public expenditures.

Analogously to the tax estimates, we control for the Canton of Basle-Town. As indicated in Section 3.1., we also have to eliminate the canton of Uri which receives a disproportionate share of federal government grants in order to fulfill its role as a main transit corridor through the Alps. The respective costs enter the cantonal budget and, thus, affect cantonal expenditures, although they are covered by the federal government. However, these expenditures do not depend on cantonal institutions. Since the infrastructural expenditures of the other cantons due to topography are also compensated by federal grants and fiscal equalization, they inflate cantonal expenditures but not taxes. Therefore, we include topography as a variable into our base regression for public spending but not for the tax burden.

Regression 1 from Table 3 confirms our hypothesis that a rising influence of the local independent competitor decreases public expenditures. The coefficient of the institutional competition variable is statistically significant at the 5 percent level and affects public spending by a large amount. A one point increase of the institutional competition variable implies an average reduction of public expenditure of about CHF 810 per capita. The maximum potential effect of institutional competition (which ranges from 0 to 3 ) is about CHF 2430 (per capita). Thus, the influence is - similar to the previous results for local and cantonal tax burden - not only statistically significant but also economically highly relevant. Moreover, the results are fairly robust to the inclusion of additional explanatory variables in regressions 2 to 5 . The result of the 2 SLS regression in column 6 reports a higher coefficient but does not reach conventional levels of statistical significance. Topography could not serve as an instrument as it is a statistically significant explanatory variable in the second stage. Unfortunately, it was impossible to identify more powerful instruments.

Looking at the remaining institutional variables as well as all the other control variables, the results look very similar to our findings for the tax burden. Local direct democracy and cantonal direct democracy do not have a significant influence on public spending in our baseline regressions. However, the respective democracy variables yield significant results if they are included separately into the estimates and are solely combined with the baseline controls population, income and topography. The simultaneous inclusion of the two variables for direct democracy at the cantonal and at the local level, respectively, produces insignificant results. ${ }^{6}$ The institutional competition variable however, is not much affected by such changes and yields consistent results.

Federalism exhibits a negative and statistically significant influence on public expenditures. For every one point increase of the federalism index, we measure an average expenditure reduction of CHF 1160. Analogous to our tax regressions, the income variable has a statistically and economically significant negative impact on public expenditures. As discussed earlier, the variable for topography exhibits a positive and significant influence

\footnotetext{
${ }^{6}$ When we drop local direct democracy from our base equation the size as well as the $t$-value of cantonal direct democracy increase but the coefficient remains statistically insignificant.
} 


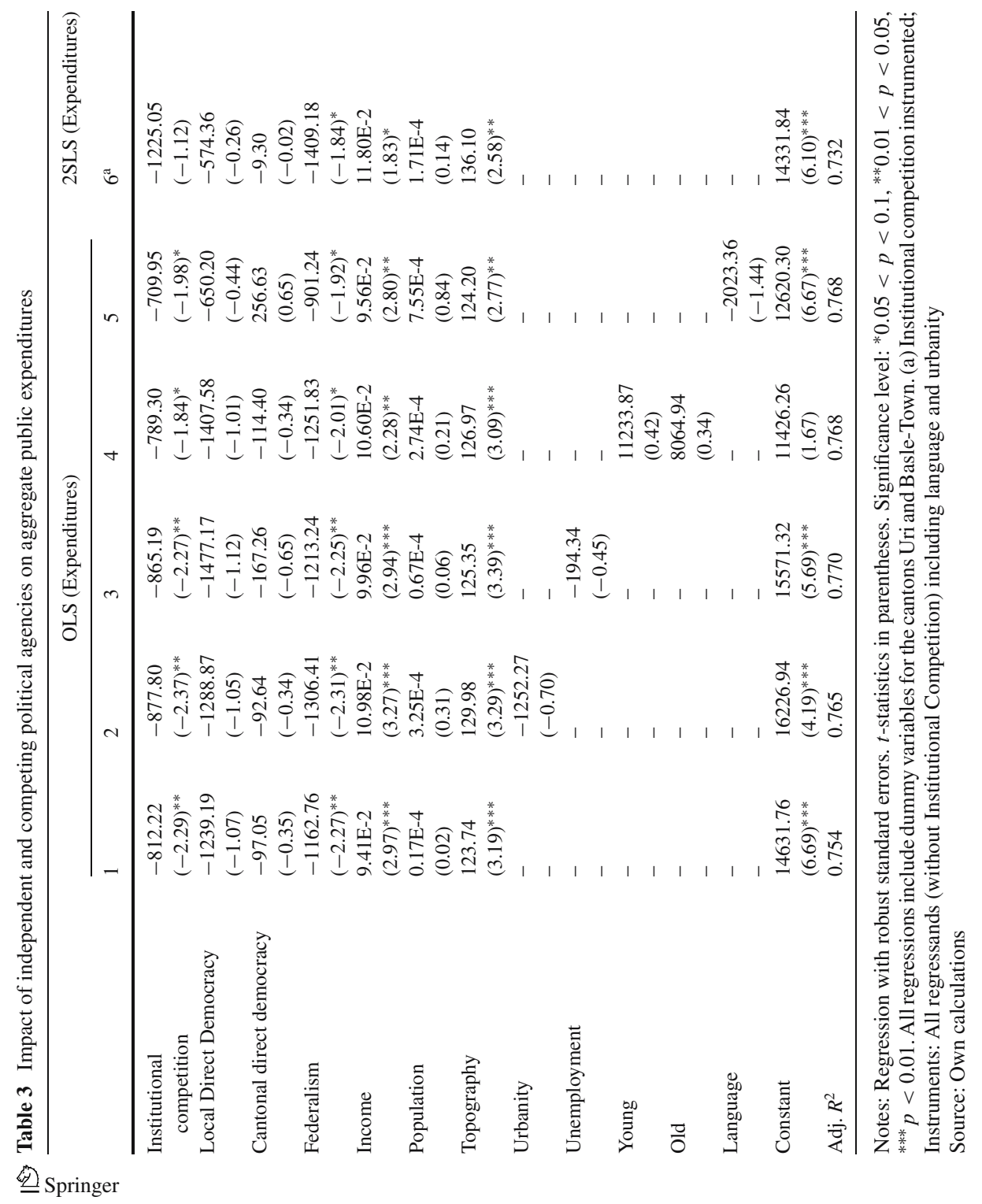


on public spending. These estimates parallel our findings reported in Table 2 and are fairly robust to the inclusion of additional explanatory variables in regressions 2 through 5. All other explanatory variable do not have a statistically significant influence on public expenditures.

\subsubsection{Robustness issues}

To further investigate the robustness of our results, we estimated different equation specifications. As reported earlier, we included and excluded insignificant variables and examined possible outlier effects. Again, the coefficient of the institutional competition variable remained unchallenged. We also included alternative measures for the extent of direct democracy such as a sub-index on the financial referendum from the index proposed by Frey and Stutzer $(2000,2001)$ and an index provided by Pommerehne and Weck-Hannemann (1996) which measures whether the population can decide on the tax rate and the budget. The results remained widely unchanged.

To make sure these results are not only valid for a specific year or constellation, we also investigate the relationships for other years. However, institutions almost by definition remain stable over time. This is also true for our institutional competition variable, which does not exhibit much variation. Consequently, a panel regression is no strict test. ${ }^{7}$ Therefore, we estimate the respective equations for several years separately. For reasons of data limitation we consider the period between 1995 and 1999. We analyze the data in the same way as presented earlier in this paper and find essentially the same results (See Table A1 in Appendix A for a short overview of these results). The coefficient for the influence of institutional competition always remains economically relevant and statistically significant. Thus, the institutional competition variable seems to be robust to the inclusion of other explanatory variables as well as to changes of the empirical setting and also yields consistent results for other years.

\section{Conclusion and outlook for future research}

Consistent with our theory, institutional competition between government and an independent political unit seem to have an important influence on public finance. Communal finance commissions with encompassing control and proposal rights exercise a statistically significant and economically relevant negative effect on the aggregated local and cantonal tax burden as well as public expenditure.

An important form of political competition has been neglected so far in the economic literature: institutionalized competition between government and an independent political unit. We discuss how this form of competition works in a system of direct democracy and provide empirical evidence for its beneficial effects on public finance. At the Swiss local level we can observe institutional competition between communal governments and communal finance commissions in municipalities with town meeting. After constructing an index, which maps the institutional design of these local finance commissions, we estimate the influence of institutional competition in a system of direct democracy. Despite the limited number

\footnotetext{
${ }^{7}$ When the data panel for 1995-1999 is used to estimate a random effects model, the results become even stronger due to the larger sample size.
} 
of observations, we find statistically significant and economically relevant negative effects on the local and cantonal tax burden as well as public expenditures. The magnitude of the estimated coefficient seems to be robust to changes in the equation specification. As the present dataset is very small, future research must address this issue with larger datasets at the local level.

So far, our results refer to the Swiss local level with its direct democracy. However, political inefficiency is even more pervasive in representative democracy (Feld \& Matsusaka, 2003), where pork-barrel politics as well as log-rolling at the expense of weakly organized interest groups are widely known phenomena (e.g. Mueller, 2003; Persson \& Tabellini, 2000). Thus, we intend to analyze how institutionalized competition can be established in a representative-democratic environment. In some major Swiss cities (e.g. Zug and Olten) with parliaments, this is already the case. There, the financial commission is directly elected by the citizens and is an independent agency which competes with the government as well as the parliament. However, these units may only perform ex post audits of the accounts, similar to audit courts and do not have encompassing audit and amendment rights. These examples show that independently elected institutions are also feasible at the parliamentary level.

Another field, where such independent and competing institutions have been neglected, is the corporate governance literature. Analogously to town meetings in political systems, shareholder meetings face similar problems. Information asymmetries between the board of directors and the shareholders are serious issues and may be addressed in analogy to our investigation. Firstly, corporate auditing firms must be able to apply freely for a limited mandate as the firm's corporate auditor directly at the shareholder meeting. There, the shareholders may choose among different auditing firms. Secondly, at the shareholder meeting, the corporate auditor needs to have encompassing proposal rights on strategic questions of the corporate policy as well as on individual projects. Analogous to our reasoning in political systems, such institutionalized competition may alter the incentives for the executive board to cater for shareholder interests.

Acknowledgements We thank Lars Feld, Bruno Frey, Michael Funk, Roland Hodler, Gerald Hosp, Gebhard Kirchgässner, Lorenz Kueng, Sonja Opper, Shauna Selvarajah, and Janez Sustercic as well as an anonymous referee for helpful and constructive comments.

\section{Appendix A}

See Table A1 on next page.

\section{Appendix B}

Table B1 provides information on the competences of financial commissions at the Swiss local level in municipalities with town meeting, the aggregated finance commission index per canton, the prevalence of town meetings (share of population living in municipalities with town meeting) as well as the product of the two indices, the institutional competition variable. 


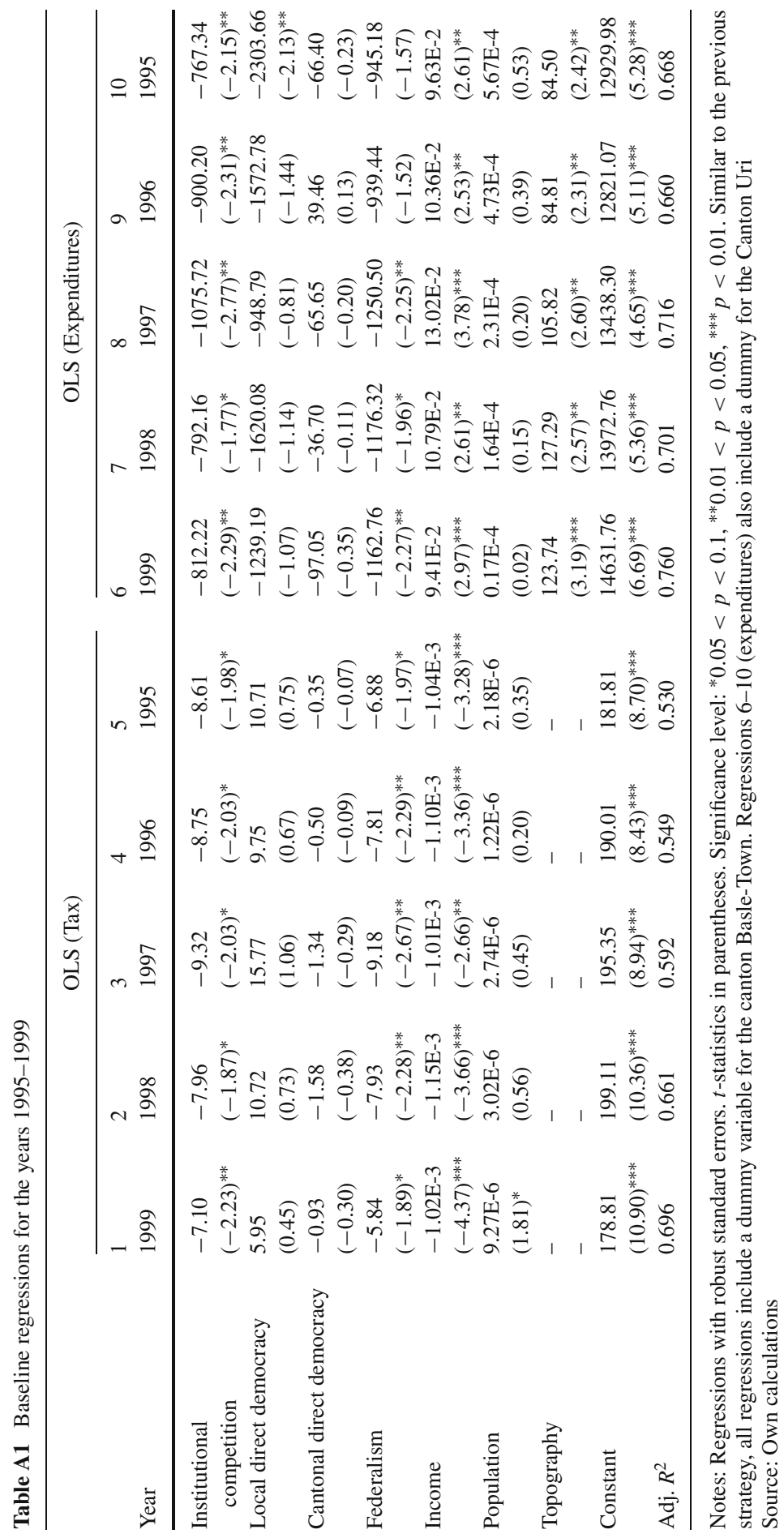




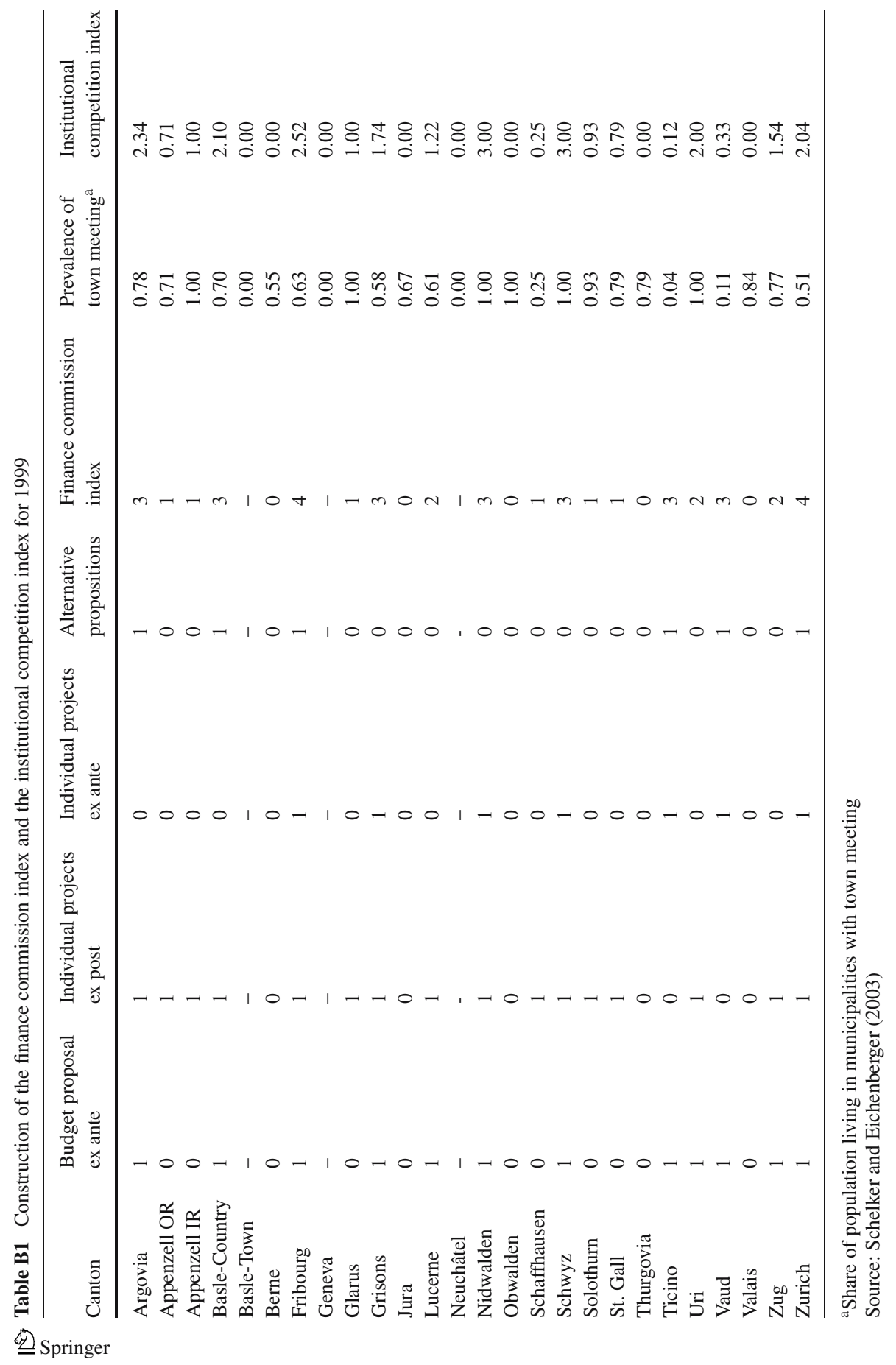




\section{References}

Alesina, A., \& Summers, L.H. (1993). Central bank independence and macroeconomic performance: some comparative evidence. Journal of Money, Credit and Banking, 25, 151-162.

Alesina, A., \& Perotti, R. (1996). Fiscal discipline and the budget process. American Economic Review, 86(2), 401-407.

Angrist, J.D., \& Krueger, A.B. (2001). Instrumental variables and the search for identification: from supply and demand to natural experiments. Journal of Economic Perspectives, 15(4), 69-85.

Besley, T., \& Case, A. (2003). Political institutions and policy choices: evidence from the United States. Journal of Economic Literature, 41, 7-73.

Berger, H., De Haan, J., \& Eijffinger, S.C.V. (2001). Central bank independence: an update of theory and evidence. Journal of Economic Surveys, 15(1), 3-40.

Bodmer, F. (2004). Why direct democracy could not stop the growth of government in Switzerland during the 1990's. Working Paper, University of Basel.

Bohn, H., \& Inman, R.P. (1996). Balanced budget rules and public deficits: evidence from the U.S. states. NBER Working Paper 5533.

Breton, A., \& Wintrobe, R. (1975). The equilibrium size of budget-maximizing bureau: a note on Niskanen's theory of bureaucracy. Journal of Political Economy, 83(1), 195-207.

Eichenberger, R. (1994). The benefits of federalism and the risk of overcentralization. Kyklos, 47, 403-420.

Eichenberger, R., \& Serna, A. (1996). Random errors, dirty information, and politics. Public Choice, 86, $137-156$.

Feld, L.P., \& Kirchgässner, G. (2001). The political economy of direct legislation: direct democracy and local decision-making. Economic Policy, 16(33), 331-367.

Feld, L.P., \& Matsusaka, J.G. (2003). Budget referendums and government spending: evidence from Swiss cantons. Journal of Public Economics, 87, 2703-2724.

Feld, L.P., \& Voigt, S. (2003). Economic growth and judicial independence: cross-country evidence using a new set of indicators. European Journal of Political Economy, 19(3), 497-527.

Feld, L.P., Kirchgässner, G., \& Schaltegger, C.A. (2003). Decentralized taxation and the size of government: evidence from Swiss state and local governments. CESIfo Working Paper No. 1087.

Forte, F., \& Eusepi, G. (1994). A profile of Italian state audit court: an agent in search of a resolute principal. European Journal of Law and Economics, 1, 151-160.

Frey, B.S. (1994). Supreme auditing institutions: a politico-economic analysis. European Journal of Law and Economics, 1, 169-176.

Frey, B.S. (1997). Not Just for the Money. An economic theory of personal motivation. Edward Elgar Publishing Limited, Cheltenham

Frey, B.S., \& Serna, A. (1990). Eine politisch-ökonomische betrachtung des rechnungshofs. Finanzarchiv, 48, 244-270.

Frey, B.S., \& Stutzer, A. (2000). Happiness, economy and institutions. Economic Journal, 110, 918-938.

Frey, B.S., \& Stutzer, A. (2001). Happiness and economics. How the economy and institutions affect human well-being. Princeton University Press, Princeton

Hagen von, J. (1991). A note on the empirical effectiveness of formal fiscal restraints. Journal of Public Economics, 44, 199-210.

Hagen von, J. (2002). Fiscal rules, fiscal institutions, and fiscal performance. The Economic and Social Review, 33(3), 263-284.

King, D.C. (1997). Turf wars. How congressional committees claim jurisdiction. University of Chicago Press, Chicago.

Kirchgässner, G. (2005). Sind direkte Demokratie und Föderalismus schuld an der Wachstumsschwäche der Schweiz? In L. Steinmann, \& H. Rentsch (Eds.), Diagnose Wachstumsschwäche. Die Debatte über die fehlende Dynamik der Schweizerischen Volkswirtschaft. Verlag Neue Zürcher Zeitung, Zürich, 175-199.

Ladner, A. (1994). Finanzkompetenzen der Gemeinden - ein Überblick über die Praxis. In F. Eng, A. Glatthard, \& B. H. Koenig (eds.), Finanzföderalismus, Emissionszentrale der Schweizer Gemeinden. Bern, 64-85

La Porta, R., Lopez-de-Silanes, F., Pop-Eleches, C., \& Shleifer, A. (2004). Judicial checks and balances. Journal of Political Economy, 112(2), 445-470.

Matsusaka, J.G. (1995). Fiscal effects of the voter initiative: evidence from the last 30 years. Journal of Political Economy, 103(3), 587-623.

Mueller, D.C. (2003). Public choice III. Cambridge University Press, Cambridge.

Niskanen, W.A. (1968). The peculiar economics of bureaucracy. American Economic Review, 58(2), 293-305.

Niskanen, W.A. (1971). Bureaucracy and representative government. Aldine-Atherton, Chicago.

Oates, W.E. (1999). An essay on fiscal federalism. Journal of Economic Literature, 37, 1120-1149. 
Persson, T., Roland, G., \& Tabellini, G. (1997). Separation of powers and political accountability. Quarterly Journal of Economics, 112, 1163-1202.

Persson, T., \& Tabellini, G. (2000). Political economics: explaining economic policy. MIT Press, Cambridge, MA.

Persson, T., \& Tabellini, G. (2004). Constitutional rules and fiscal policy outcomes. American Economic Review, 94(1), 25-45.

Poterba, J.M. (1996). Budget institutions and fiscal policy in the U.S. states. American Economic Review, $86(2), 395-400$.

Pujol, F., \& Weber, L. (2003). Are preferences for fiscal discipline endogenous? Public Choice, 114, 421-444.

Shepsle, K.A., \& Weingast, B.R. (1994). Positive theories of congressional institutions. Legislative Studies Quarterly, 19(2), 149-179

Schaltegger, C.A. (2001). Ist der Schweizer Föderalismus zu kleinräumig? Swiss Political Science Review, 7 , $1-18$.

Schaltegger, C.A. (2002). Budgetregeln und ihre Wirkung auf die öffentlichen Haushalte: Empirische Ergebnisse aus den US-Bundesstaaten und den Schweizer Kantonen Schmollers Jahrbuch, 122, 369-413.

Schaltegger, C.A., \& Feld, L.P. (2001). On government centralization and budget referendums: evidence from Switzerland. CESifo, Munich.

Schelker, M. (2002). Öffentliche Finanzen und Rechnungsprüfungsorgane: Eine empirische Studie. Mimeo, Center for Public Finance, University of Fribourg.

Schelker, M., \& Eichenberger, R. (2003). Starke Rechnungsprüfungskommissionen: Wichtiger als direkte Demokratie und Föderalismus? Ein erster Blick auf die Daten. Swiss Journal of Economics and Statistics, 139(3), 351-373.

Streim, H. (1994). Agency problems in the legal political system and supreme auditing institutions. European Journal of Law and Economics, 1, 117-191.

Stutzer, A. (1999). Demokratieindizes für die Kantone der Schweiz. Working Paper No. 23, Institute for Empirical Research in Economics, University of Zurich.

Weingast, B.R., \& Marshall, W.J. (1988). The industrial organization of congress; or, why legislatures, like firms, are not organized as markets. Journal of Political Economy, 96, 132-163. 